Reviu Akuntansi dan Bisnis Indonesia, Vol. 4 No. 1, Hlm: 93-102, Juli 2020

Website: http://journal.umy.ac.id/index.php/rab

\title{
Faktor Penentu Perusahaan Melakukan Penghindaran Pajak
}

\author{
Adam Zain Pratama ${ }^{1 *}$, Alek Murtin \\ 'Program Studi Akuntansi Universitas Muhammadiyah Yogyakarta
}

IN F O A R T I K EL

\section{Kata Kunci:}

penghindaran pajak, profitabilitas, leverage, ukuran perusahaan, dan kepemilikan institusional.

Jenis Artikel:

Penelitian Empiris

\section{Korespondensi:} zain.adam70@gmail.com

\section{A B S T RA K}

\section{Latar Belakang:}

Perusahaan maunfaktur merupakan bagian dari sektor yang berkontribusi besar terhadap penerimaan pajak Negara, dibandingkan sektor seperti perkebunan, pertambangan, dan keuangan dan lainnya. Perusahaan manufaktur merupakan bagian dari wajib pajak yang terfokus dalam daftar pemeriksaan Direktorat Jendral Pajak. Maka perlu dilakukan penelitian untuk membuktilan faktor penentu Perusahaan manufaktur dalam melakukan penghindaran pajak, dikarenakan bagi perusahaan pajak merupakan biaya atau cash outflow sehingga sangat hati-hati dalam melakukan perhitungan pajaknya.

Tujuan:

Penelitian ini bertujuan untuk menganalisis dan memberikan bukti empiris tentang variabel profitabilitas, vaiabel leverage, variabel ukuran perusahaan, dan variabel kepemilikan institusional terhadap variabel penghindaran pajak. Adapun penghindaran pajak atau tax avidance merupakan penghindaran pajak yang diperkenankan dalam perpapajakan dan tidak bertentangan dengaan peraturan perudang-undangan perpajakan juga tidak bertentangan dengan aturan akuntansi.

\section{Metode Penelitian:}

Populasi dalam penelitian ini adalah perusahaan manufaktur yang terdaftar di Bursa Efek Indonesia 2016-2018. Data dikumpulkan dengan menggunakan metode purposive sampling dengan data sebanyak 384 data perusahahaan manufaktur yang terdaftar di Bursa Efek Indonesia yang bisa diolah sebanyak 108 data. Purposivenya berupa Tidak tersedianya data laporan keuangan dan laporan tahunan, Data Perusahaan Manufaktur yang menggunakan mata uang selain rupiah dan Data Perusahaan Manufaktur yang memiliki laba negative . Analisis yang digunakan dalam penelitian ini adalah analisis regresi linier berganda dengan bantuan software SPSS 15.0

\section{Hasil Penelitian}

Hasil olah data dalam penelitian ini menyatakan medapatkan hasil bahwa variabel profitabilitas dan variabel kepemilikan institusional berpengaruh terhadap penghindaran pajak. Sedangkan variabel leverage dan variabel ukuran perusahaan tidak berpengaruh secara signifikan terhadap variabel penghindaran pajak.

\section{Keterbatasan Penelitian:}

Hasil penelitian hanya variabel profitabilitas dan kepemilikan institusional saja, perlu menambahkan variabel lain peperti auditor ekternal, kepemilikan saham oleh keluarga dan lain-lain. Penelitian ini hanya sebatas perusahaan manufaktur, maka perlu ada penelitian untuk perusahaan tambang, industri kimia, jasa dan dagang untuk melihat perbedaan.

Keaslian/Novetly Penelitian:

Penelitian terkait pajak masih terus berkembang, khususnya tentang penghindaran pajak. Dan penelitian ini memberikan diskusi baru untuk bidang perpajakan untuk bidang manufaktur. 


\section{PENDAHULUAN}

Pajak merupakan pendapatan negara terbesar dibandingkan dengan pendapatan APBN lainnnya, hal ini dampak dari perubahan sistem perpajakan dari sistem official assesment sejak tahun 1984 menjadi self assesment, merupakan sistem yang dalam pemungutan pajaknya diserahkan wajib pajak orang pribadi itu sendiri maupun badan dalam menghitung, menyetor, dan melaporkan pajak kepada Negara (Hutagaol, 2013). Wajib pajak berusaha menghindari pembayaran pajak untuk mengurangi jumlah pajak yang harus dibayar.

Penghindaran pajak dapat diartikan sebagai metode minimalisasi penyetoran pajak oleh wajib pajak dengan cara mengurangi jumlah tagihan pajaknya tanpa harus melanggar peraturan perpajakan atau bisa diperjelas dengan mencari titik lemah peraturan (Hutagaol, 2007), penghadiaran penyetoran pajak bagi negara mengurangi pendapatan APBN.

Sebagian perusahaan memilih memaksimalkan laba sebesar-besarnya akan tetapi perusahaan menerapkan efisiensi ketat terhadap biaya pajak (Utami, 2013). Walupun memiliki risiko jika ada pemeriksaan akan dikenakan sanksi jika efisiensi pajak melanggar undang ungdang perpajakan.

Penelitian Maharani (2014) menyatakan bahwa profitabilitas merupakan faktor yang mempengaruhi manajemen melakukan penghindaran pajak. Rasio ROA sebagai indikator performa keuangan perusahaan menentukan bagaimana hasil performa tersebut. Hasil dari penelitian tersebut bertentangan dengan penelitian oleh Utami (2013) yang menyatakan bahwa profitabilitas tidak berpengaruh terhadap penghindaran pajak.

Dalam penelitian Kurniasih dan Sari (2013) pengaruh ukuran perusahaan terhadap penghindaran pajak menunjukan hasil bahwa ukuran perusahaan berpengaruh terhadap penghindaran pajak. Ukuran perusahaan diidentifikasikan dengan besar total asset, pada perusahaan menandakan semakin besar asset menujukkan pula semakin besar ukuran perusahaan, hasil ini di dukung penelitian yang dilakukan Richardson dan Lanis (2007). Namun penelitian ini bertolak belakang dengan hasil penelitian yang dilakukan oleh Dewi dan Jati (2014) yang menyatakan bahwa ukuran perusahaan tidak berpengaruh terhadap penghindaran pajak.

Penelitian pengaruh ukuran perusahaan terhadap penghindaran pajak yang dilakukan oleh Kurniasih dan Sari (2013) menunjukan hasil bahwa ukuran perusahaan berpengaruh terhadap penghindaran pajak. Semakin besar total asset pada perusahaan menandakan semakin besar pula ukuran perusahaan. Ukuran perusahaan dapat mempengaruhi perusahaan dalam menghindari pajaknya. Hasil tersebut didukung penelitian yang dilakukan Richardson dan Lanis (2007). Namun penelitian ini bertolak belakang dengan hasil penelitian yang dilakukan oleh Dewi dan Jati (2014) yang menyatakan bahwa ukuran perusahaan tidak berpengaruh terhadap penghindaran pajak.

Kemudian penelitian Swingly (2015) menyatakan leverage merupakan faktor yang mempengaruhi penghindaran pajak. Dalam penelitiannya yang dilakukan, diperoleh hasil bahwa leverage berpengaruh positif terhadap penghindaran pajak. Sedangkan Agusti (2014) memperoleh hasil penelitian yang menyatakan bahwa leverage tidak memiliki pengaruh terhadap penghindaran pajak.

Penelitian Dewi dan Jati (2014) yang membahas pengaruh kepemilikan institusional terhadap penghindaran pajak memuat hasil bahwa kepemilikan institusional tidak memiliki pengaruh terhadap tingkat penghindaran pajak di suatu perusahaan. Penelitian tersebut didukung oleh Annisa dan Kurniasih (2012). Namun penelitian Pranata, Puspa, Herawati (2013) menghasilkan hasil yang bertolak belakang, menyatakan bahwa kepemilikan institusional memiliki pengaruh terhadap penghindaran pajak.

Penelitian ini akan dilakukan pada perusahaan manufaktur yang telah terdaftar di Bursa Efek Indonesia (BEI) dari tahun 2016-2018. Pemilihan perusahaan manufaktur sebagai objek penelitian didasarkan beberapa alasan. Yang pertama adalah karena perusahaan maunfaktur merupakan bagian dari sektor yang berkontribusi besar terhadap penerimaan pajak Negara, dibandingkan sektor seperti perkebunan, pertambangan, dan keuangan dan lainnya. Dan yang kedua adalah karena perusahaan manufaktur merupakan bagian dari wajib pajak yang terfokus dalam daftar pemeriksaan Direktorat Jendral Pajak. 


\section{TINJAUAN LITERATUR DAN PERUMUSAN HIPOTESIS}

\section{Teori Agensi}

Konsep agensi teori menurut Anthony dan Govindarajan dalam Siagian (2011) bisa dimisalkan dengan kontak antara principal dan agen. Peran principal yaitu memberi perintah kepada agen untuk menyelesaikan tugasnya terkait dengan kepentingan principal, termasuk pelimpahan wewenang dalam menentukan keputusan dari principal kepada agen. Sedangkan agen tidak selamanya setuju untuk menerima perintah principal, melainkan agen juga ingin melakukan tugas untuk kepentingannya sendiri.

Konflik agensi terbagi menjadi dua bentuk. Bentuk pertama adalah antara manajer dengan pemegang saham. Pelopor terjadinya konflik yang dilakukan menajer dengan pemegang saham adalah pembentukan keputusan dalam hal kegiatan pengumpulan dana serta dalam hal yang berhubungan dengan bagaimana menginvestasikan dana yang didapat. Bentuk kedua adalah konflik agensi antara pemegang saham dengan kreditor (Kirana, 2007).

Dalam menjalankan kepentingannya, principal memberi pengorbanan atas sumber dayanya dalam bentuk kompensasi yang akan diserahkan kepada agen. Dimana dalam kompensasi tersebut diharapkan principal dapat mengurangi tindakan agen yang mungkin berisiko terhadap kepentingan principal. Biaya tersebut adalah monitoring cost. Agen juga memberi jaminan kepada principal dengan tidak membahayakan principal. Apabila hal tersebut membahayakan, maka agen akan bertanggung jawab dengan memberikan biaya kepada principal. Biaya tersebut adalah bonding cost.

Dalam kaitannya dengan penghindaran pajak, teori keagenan ini mempunyai arti bahwa ketika principal memberi kompensasi kepada agen. Kemudian ketika kompensasi itu diterima, maka agen termotivasi untuk meningkatkan kinerja dengan harapan tidak mengecewakan principal. Termasuk usahanya dalam mengefisiensikan pembayaran pajak perusahaan.

\section{Penghindaran Pajak}

Penghindaran pajak merupakan usaha dalam meminimalisasi, mencegah, serta mempermudah beban pajak melalui metode yang tidak melanggar hukum atau sesuai dengan ketentuan perpajakan dengan tetap mempertimbangkan kemungkinan suatu dampak pajak yang terjadi (Ernest R. Mortenson dalam Zain : 2008).

Menurut data dari Organization for Economic Cooperation and Development (OECD) dalam Fadhilah, (2014) membuahkan tiga karakter dari penghindaran pajak :

1. Terdapat unsur artifisial dimana seolah-olah ada berbagai pengaturan didalamnya namun sebenarnya tidak ada, melainkan karna ketiadaan faktor pajak.

2. Menerapkan cara atau ketentuan legal menurut undang-undang bagaimana pun bentuknya, padahal yang dimaksudkan undang-undang berbeda.

3. Para konsultan menujukan metode untuk menghindari pajak dengan memberi syarat agar wajib pajak tidak membocorkan rahasia tersebut (Council of Executif Secretaries of Tax Organization, 1991)

\section{Profitabilitas}

Menurut Standar Akuntansi Keuangan (2009), indikator kinerja perusahaan dengan profitabilitas yang baik dibutuhkan untuk menentukan perubahan potensial sumber daya ekonomi masa depan. Ketika prospek yang dijalankan terlihat menarik maka akan menarik minat investor untuk berinvestasi dalam suatu perusahaan sehingga diperlukan penjelasan yang lebih lengkap dan luas pada laporan tahunan perusahaan.

Beberapa perhitungan rasio yang diterapkan dalam menghitung profitabilitas adalah Return On Asset (ROA). ROA memiliki hubungan dengan laba bersih dan pengenaan pajak penghasilan perusahaan. 
Menurut hasil penelitian Maharani (2014) ketika sebuah ROA perusahaan menunjukan grafik yang tinggi, maka yang terjadi adalah profitabilitasnya pun akan tinggi. Hal ini dikarenakan ketika laba meningkat, maka jumlah pajak penghasilan pun akan meningkat. Oleh karena itu, maka diturunkan hipotesis sebagai berikut:

$\mathbf{H}_{1}$ : Profitabilitas berpengaruh negatif terhadap penghindaran pajak

\section{Leverage}

Dari pernyataan Irfan Fahmi (2012) leverage mempunyai arti sebagai pengukur besarnya perusahaan yang dalam menjalankan aktivitasnya dibiayai dengan pinjaman atau hutang. Dengan menggunakan rasio leverage, maka perusahaan dapat diukur sejauh mana kemampuannya melalui sumber modal yang dibiayai oleh hutang atau pihak luar.

Manfaat yang diperoleh perusahaan dari leverage sangat banyak, baik dari rasio yang rendah atau pun tinggi. Menurut Fred Waston, dalam Ngadiman dan Puspitasari (2014) leverage memiliki beberapa implikasi, yaitu:

1. Kreditor menginginkan ekuitas atau dana dari pemilik sebagai jaminan atau keuangan. Hal tersebut berakibat bahwa jika pemilik mempunyai dana yang lebih sedikit sebagai modal, maka kreditor akan menanggung risiko bisnis terbesar.

2. Ketika mendapatkan dana melaui utang, maka pemilik memperoleh keuntungan berupa masih tetap memiliki hak untuk mengendalikan perusahaan.

3. Apabila perusahaan berpenghasilan melebihi dana yang dipinjam dibanding dengan bunga yang dibayarkannya, maka pengembalian kepada pemilik diperbesar.

Beban bunga termasuk ke dalam beban yang bisa meminimalisasi pendapatan yang terkena pajak (deductible expense), oleh karenanya pemakaian hutang akan membuat hubungan yang baik terhadap kegiatan penghindaran pajak oleh suau perusahaan. Sebuah penelitian terkait leverage pernah dilakukan oleh Fadilla Rachmitasari (2015) yang mengemukakan bahwa leverage memiliki pengaruh positif terhadap penghindaran pajak.

Menurut hasil penelitian Fadilla Rachmatisari (2015), ketika nilai dari rasio sebuah leverage menghasilkan grafik yang tinggi, maka akan bertambah tinggi juga total pendanaan dari utang pihak ke tiga yang digunakan perusahaan. Biaya bunga pun akan semakin tinggi karena utang tersebut, dan akan mengurangi beban pajak perusahaan. Ketika nilai utang perusahaan bertambah tinggi, maka nilai CETR (Cash Effective Tax Rate) perusahaan akan bertambah rendah. Maka diturunkan hipotesis sebagai berikut:

$\mathbf{H}_{2}$ : Leverage berpengaruh positif terhadap penghindaran pajak

\section{Ukuran Perusahaan}

Tahap kedewasaan perusahaan akan terlihat dari berapa jumlah total aset, ketika total aset bertambah besar, maka artinya perusahaan memiliki riwayat kinerja yang baik dalam rentang waktu yang lama, (Dharma dan Ardiana, 2015).

Semakin besar sebuah perusahaan, maka kebutuhan dana perusahaan pun akan semakin besar. Oleh sebab itu, perusahaan harus memperoleh pendapatan yang besar agar mampu memenuhi kebutuhannya. Karena dalam memenuhi kebutuhannya, akan menentukan apakah investor tetap bertahan dengan investasinya atau sebaliknya. Jadi artinya, perusahaan mempunyai kemungkinan untuk melakukan penghindaran pajak agar perusahaannya tetap mampu untuk memenuhi kebutuhannya dan investor tetap melakukan investasinya. Dalam perusahaan yang mempunyai operasi lintas negara, penghindaran pajak dapat dilakukan karena perusahaan dapat 
mentransfer laba ke perusahaan yang ada di negara lain, dimana negara tersebut memungut tarif pajak yang lebih rendah dibandingkan negara lainnya.

Perusahaan dengan ukuran yang besar akan bertambah kompleks transaksinya sehingga akan terbuka kemungkinan yang dimanfaatkan dalam melancarkan aktivitas penghindaran pajak, (Rego, 2003). Penelitian terkait pernah dilakukan oleh Kurniasih dan Sari (2013) yang mengemukakan bahwa ukuran perusahaan mempunyai pengaruh signifikan terhadap penghindaran pajak.

Dari hasil penelitian yang dilakukan oleh Kurniasih dan Sari (2013), ketika ukuran sebuah perusahaan semakin besar maka CETR yang dimiliki akan semakin rendah. Alasannya adalah karena perusahaan besar lebih mampu menggunakan sumber daya yang dimilikinya untuk membuat suatu perencanaan pajak yang baik. Perencanaan tersebut dimanfaatkan perusahaan besar dalam mengatur laba yang dilaporkan dari setiap periode Ketika perusahaan besar memiliki banyak aktivitas operasi dan rumit, maka terdapat celah perusahaan untuk menghindari pajak. Sedangkan perusahaan kecil mempunyai keterbatasan aktivitas sehingga susah untuk menghindari pajak. Dengan demikian, maka dapat diturunkan hipotesis sebagai berikut:

$\mathbf{H}_{3}$ : Ukuran Perusahaan berpengaruh positif terhadap penghindaran pajak

\section{Kepemilikan Institusional}

Maksud dari kepemilikan institusional merupakan suatu kepemilikan saham perusahaan yang dimiliki institusi keuangan seperti bank, perusahaan asuransi, dana pensiun, dan investasi bank, (Veronica dan Utama, 2005). Dengan kepimilikan investor institusional seperti perusahaan asuransi, perusahaan efek, perbankan, perusahaan investasi, dana pensiun, dan kepemilikan institusi yang lain akan mempercepat perkembangan penjagaan yang tepat dan ideal terhadap kemampuan manajemen, karena kepemilikan saham merupakan perwakilan dari sumber kekuasaan (Source of Power) yang dimanfaatkan untuk mendukung keberadaan manajemen atau malah sebaliknya (Kartikawati, 2009).

Besar atau kecilnya sebuah kepemilikan institusional, akan memiliki pengaruh terhadap kebijakan pajak perusahaan. Ketika kepemilikan institusional terpaut kecil, maka akan meningkatkan keputusan untuk menghindari pajak. Namun apabila kepemilikan institusional terpaut besar, maka akan mengurangi keputusan untuk menghindari pajak (Merslythalia dan Lasmana, 2016).

Menurut hasil penelitian Merslythalia dan Lasmana (2016), besar kecilnya presentasi kepemilikan saham mempunyai peluang untuk menentukan keputusan yang diambil. Ketika investor terhitung memiliki kepemilikan saham yang besar, maka invetor akan semakin berani untuk mendesak manajer sesuai dengan keinginannya. Hal tersebut mengakibatkan manajer susah untuk melakukan aktivitas penghindaran pajak. Dengan demikian, maka dapat diturunkan hipotesis sebagai berikut:

$\mathbf{H}_{4}$ : Kepemilikan Institusional berpengaruh negatif terhadap penghindaran pajak

\section{METODE PENELITIAN}

\section{Uji Kualitas Instrumen dan Data}

\section{Uji Statistik Deskriptif}

Hasil statistik deskriptif disajikan dalam table 4.1 sebagai berikut : 
Tabel 4.1

Hasil Uji Statistik Deskriptif

\begin{tabular}{lccccc}
\hline \multicolumn{1}{c}{ Variabel } & N & Min & Max & Mean & Std. Deviation \\
\hline Penghindaran Pajak & 108 & 0,05 & 1,17 & 0,3735 & 0,17063 \\
Profitabilitas & 108 & 0,00 & 0,30 & 0,0971 & 0,06594 \\
Leverage & 108 & 0,14 & 2,19 & 0,6355 & 0,49003 \\
Ukuran Perusahaan & 108 & 11,13 & 13,96 & 12,409 & 0,69839 \\
Kepemilikan Institusional & 108 & 0,32 & 0,99 & 0,7177 & 0,17505 \\
Valid N (listwise) & 108 & & & & \\
\hline
\end{tabular}

Sumber Output SPSS 15.0

\section{Uji Asumsi Klasik}

a. Uji Normalitas

Uji normalitas yang digunakan dalam penelitian ini adalah One-Sample Kolmogorov Smirnov Test. Hasil dari uji normalitas sebagai berikut:

Tabel 4.2

Hasil Uji Normalitas

\begin{tabular}{lll}
\hline Variabel & Probabilitas & Keterangan \\
\hline Residual Regresion & 0,357 & Normal \\
\hline Sumber Output SPSS 15.0 & &
\end{tabular}

b. Uji Multikolinieritas

Uji Multikoliniearitas merupakan sebuah uji untuk mengetahui apakah ada kolerasi antarvariabel bebas (independent) dan pengambilan kesimpulan mengenai pengaruh pada suatu model regresi (Nazaruddin dan Basuki, 2016). Menurut Singgih (2000) suatu model regresi yang bebas dari multikolinieritas adalah apabila mempunyai Nilai VIF lebih kecil 10 dan mempunyai angka Tolerance mendekati 1 .

Hasil uji multikoliniearitas dipresentasikan pada table berikut:

Tabel 4.3

Hasil Uji Multikoliniearitas

\begin{tabular}{lccc}
\hline \multicolumn{1}{c}{ Model } & \multicolumn{2}{c}{ Collinearity Statistics } & \multirow{2}{*}{ Keterangan } \\
& Tolerance & VIF & Terbebas dari Multikolinieritas \\
\hline Profitabilitas & 0.763 & 1.310 & Terbebas dari Multikolinieritas \\
Leverage & 0.774 & 1.292 & Terbebas dari Multikolinieritas \\
Ukuran Perusahaan & 0.936 & 1.068 & Terbebas dari Multikolinieritas \\
Kepemilikan & 0.967 & 1.034 &
\end{tabular}

Sumber Output SPSS 15.0

c. Uji Heteroskedastisitas

Uji Heteroskedastisitas digunakan untuk mengetahui apakah dalam model regresi terjadi ketidaksamaan varian dari residual untuk semua pengamatan pada model regresi (Nazaruddin dan Basuki, 2016). Uji ini sangat penting dilakukan karena uji heteroskedastisitas berfungsi untuk mengetahui adanya penyimpangan dari syarat-syarat asumsi klasik pada model regresi. Hasil uji heteroskedastisitas diperlihatkan pada table berikut: 
Tabel 4.4

Hasil Uji Heteroskedastisitas

\begin{tabular}{lcl}
\hline \multicolumn{1}{c}{ Variabel } & Nilai Sig. & Keterangan \\
\hline Profitabilitas & 0.064 & Terbebas dari Heteroskedastisitas \\
Leverage & 0.733 & Terbebas dari Heteroskedastisitas \\
Ukuran Perusahaan & 0.334 & Terbebas dari Heteroskedastisitas \\
Kepemilikan Institusional & 0.571 & Terbebas dari Heteroskedastisitas \\
\hline
\end{tabular}

d. Uji Autokorelasi

Uji Autokorelasi digunakan untuk mengetahui adanya penyimpangan atau tidaknya pada suatu data. Arti dari penyimpangan sendiri adalah hubungan antara satu dengan lainnya (Nazaruddin dan Basuki, 2016). Hasil uji autokorelasi ditunjukan pada tabel berikut:

Tabel 4.5

Hasil Uji Autokorelasi

\begin{tabular}{cccccc}
\hline Model & $\mathrm{R}$ & R Square & Adjust R Square & $\begin{array}{c}\text { Std. Eror of the } \\
\text { Estimate }\end{array}$ & $\begin{array}{c}\text { Durbin- } \\
\text { Watson }\end{array}$ \\
\hline 1 &, $603^{\mathrm{a}}$ &, 363 &, 338 & .13878 & 2,222 \\
\hline Sumber Output SPSS & 15.0 & &
\end{tabular}

\section{HASIL DAN PEMBAHASAN}

Hasil uji hipotesis analisis regresi disimpulkan pada table 4.6 sebagai berikut:

Tabel 4.6

Hasil Analisis Regresi Linier Berganda

\begin{tabular}{lcccl}
\hline \multicolumn{1}{c}{ Variabel } & Koef. Regresi & T-Statistic & Sig & \multicolumn{1}{c}{ Keterangan } \\
\hline Penghindaran Pajak & & & 0,065 & Signifikan \\
Profitabilitas & $-0,409$ & 0,763 & 0,000 & \\
Leverage & $-0,161$ & 0,774 & 0,115 & Tidak Signifikan \\
Ukuran Perusahaan & 0,043 & 0,936 & 0,641 & Tidak Signifikan \\
Kepemilikan Institusional & $-0,216$ & 0,967 & 0,018 & Signifikan \\
\hline
\end{tabular}

Sumber Output SPSS 15.0

1. Uji Regresi Berganda

Ditarik kesimpulan dari regresi berganda adalah sebagai berikut:

Penghindaran Pajak $=0,65+(-0,183)$ Profita $+(-0,013)$ Lev $+(-0,087)$ Size $+(-0,161)$ KI $+2,055$

2. Uji Signifikan Secara Simultan (Uji-F)

Tabel 4.6

Uji F

\begin{tabular}{lccccc}
\hline \multicolumn{1}{c}{ Model } & $\begin{array}{c}\text { Sum of } \\
\text { Squares }\end{array}$ & Df & Mean Square & F & Sig. \\
\hline Regression & 0,578 & 4 & 0,145 & 5,866 & 0,000 (a) \\
Residual & 2,537 & 136 & 0,025 & & \\
Total & 3,115 & 140 & & & \\
\hline
\end{tabular}

Sumber Output SPSS 15.0 


\section{Hasil Uji Hipotesis}

Berdasarkan tabel 4.6 yang menghasilkan sebuah pengujian analisis regresi linier berganda, dapat diperoleh kesimpulan hasil hipotesis sebagai berikut:

a. Pengaruh profitabilitas terhadap penghindaran pajak

Berdasarkan table 4.6 menyatakan bahwa variabel profitabilitas memiliki koefisien regresi unsur negatif sebanyak -0,409 dan nilai sig sebesar 0,00). Tingkat signifikansi variabel profitabilitas lebih kecil dari alpha $(\alpha)$ 0,05. Hal ini menunjukan bahwa secara parsial profitabilitas berpengaruh negatif terhadap penghindaran pajak. Dengan demikian hasil H1 adalah berhasil didukung.

b. Pengaruh leverage terhadap penghindaran pajak

Berdasarkan table 4.6 menyatakan bahwa variabel leverage memiliki koefisien regresi unsur negatif sebesar -0,161 dan nilai sig. sebesar 0,115. Tingkat signifikansi variabel leverage lebih besar dari alpha $(\alpha)$,0,5. Hal ini menunjukan bahwa secara parsial leverage tidak berpengaruh terhadap penghindaran pajak. Oleh sebab itu, H2 tidak berhasil didukung.

c. Pengaruh ukuran perusahaan terhadap penghindaran pajak

Berdasarkan table 4.6 menyatakan bahwa variabel ukuran perusahaan memiliki koefisien regresi unsur positif sebesar 0,043 dan nilai sig. sebesar 0,641. Tingkat signifikansi variabel ukuran perusahaan lebih besar dari alpha $(\alpha)$ 0,05. Hal ini menunjukan bahwa secara parsial ukuran perusahaan tidak berpengaruh terhadap penghindaran pajak. Oleh sebab itu, H3 tidak berhasil didukung.

d. Pengaruh kepemilikan institusional terhadap penghindaran pajak

Berdasarkan table 4.6 menyatakan bahwa variabel kepemilikan institusional memiliki koefisien regresi unsur negatif sebesar -0,216 dan nilai sig. sebesar 0,018. Tingkat signifikansi variabel kepemilikan institusional lebih kecil dari alpha $(\alpha) 0,05$. Hal ini menunjukan bahwa secara parsial kepemilikan institusional perusahaan memiliki pengaruh terhadap penghindaran pajak. Oleh sebab itu H4 berhasil didukung.

\section{Uji Adjusted R Squared (Adj. R')}

Koefisien determinasi pada intinya adalah menghitung seberapa jauh kemampuan model dalam menjelaskan variasi variabel dependen. Nilai koefisien determinasi adalah nol dan satu. Berdasarkan table 4.5 diketahui 0,338 dapat diartikan bahwa penghindaran pajak 34\% dapat dijelaskan oleh variabel profitabilitas, leverage, ukuran perusahaan, dan kepemilikan institusional. Sisanya $66 \%$ dijelaskan variabel lainnya yang tidak diuji dalam penelitian ini.

\section{KESIMPULAN}

Hasil penelitian menyimpulkan bahwa semakin tinggi tingkat profitabilitas sebuah perusahaan maka tingkat manajemen perusahaan dalam mengelola laba akan semakin baik. Dengan pengendalian manajemen yang baik maka perusahaan akan lebih siap dalam membayar paja. Kondisi ini menyebabkan perusahaan tidak memikirkan upaya untuk menghindari pajak. Walau pun modal perusahaan yang diperoleh secara utang mengakibatkan biaya pajak menjadi kecil, tetapi manajer lebih menghindari utang sebagai modal karna risiko di masa depan yang belum bisa diprediksi. Kondisi ini menyebabkan perusahaan tidak memikirkan upaya menghindari pajak 
melalui leverage. Semakin besarnya ukuran sebuah perusahaan diperoleh dari cara perusahaan tersebut memperoleh laba. Semakin besarnya laba yang diperoleh, maka perusahaan akan semakin mudah untuk membayarkan segala kewajiban pajaknya. Kondisi ini menyebabkan perusahaan tidak memikirkan upaya untuk menghindari pajak. Ketika kepemilikan saham lebih dominan dimiliki oleh investor, maka yang terjadi adalah manajer akan merasa kesulitan untuk melakukan upaya penghindaran pajak karna selalu terawasi investor. Kondisi ini menyebabkan perusahaan akan sulit untuk berupaya menghindari pajak.

\section{DAFTAR PUSTAKA}

Agusti, W. Y. (2014). Pengaruh Profitabilitas, Leverage, dan Corporate Governance terhadap Tax Avoidance. Jurnal Akuntansi Volume 2/No.3.

Annisa, N. A. \& Kurniasih, L. (2012). Pengaruh Corporate Governance terhadap Tax Avoidance. Jurnal Akuntansi dan Auditing Volume 8/No.2.

Anthony \& Govindaraja. (2011). Sistem Pengendalian Manajemen. Jilid 2. Tanggerang: Karisma Publishing Group.

Arianandini, P. W. \& Ramantha, I. W. (2018). Pengaruh Profitabilitas, Leverage, dan Kepemilikan Institusional pada Tax Avoidance. E-Jurnal Akuntansi Universitas Udayana ISSN: 20882116.

Council of Executif Sectretaries of Tax Organization. (1991).

Desai, M. A., \& Dharmapala, D. (2006). Corporate Tax Avoidance and High Powered Incentives. Journal of Financial Economics, 79(1), 145-179.

Dewi, K \& I. K Jati. (2014). Pengaruh Karakter Eksekutif, Karakteristik Perusahaan, dan Corporate Governance pada Tax Avoidance di Bursa Efek Indonesia. E-Jurnal Akuntansi ISSN 23028556 6.2: 249-260.

Dharma, I. M. S. \& Ardiana, P. A. (2016). Pengaruh Leverage, Intensitas Aset Tetap, Ukuran Perusahaan, dan Koneksi Politik Terhadap Tax Avoidance. E-Jurnal Akuntansi Udayana. Vol. 15, No. 1. ISSN: 2302-8556.

Direktorat Jenderal pajak. (2009). Undang-undang Nomor 16 Tahun 2009 tentang Perubahan Ketiga atas Undang-undang Nomor 6 tahun 1983 tentang Ketentuan Umum dan tata Cara Perpajakan.

Fadhilah, R. (2014). Pengaruh Good Corporate Governance Terhadap Tax Avoidance (Studi Empiris pada Perusahaan Manufaktur yang Terdaftar Di Bursa Efek Indonesia 2009-2011). Jurnal Akuntansi Universitas Negeri Padang, 2 (1).

Fahmi, I. (2012). Analisis Kinerja Keuangan. Bandung: Alfabeta.

Hutagaol, J. (2007). Perpajakan Isu-isu Kontemporer. Jakarta: Graha Ilmu.

Hutagaol, K. (2013). Pembelajaran Kontekstual untuk Meningkatkan Representasi Matematis Siswa Sekolah Menengah Pertama. Jurnal Ilmiah Program Studi Matematika STKIP Siliwangi Bandung, 2 (1). 85-99.

Ikatan Akuntansi Indonesia. (2009). Standar Akuntansi Keuangan. PSAK No. 1 : Penyajian Laporan Keuangan Jakarta : Salemba Empat.

Jaya, W. K. (2007). The Role of the State in the case of Indonesia Local Tax Reform. Journal of Indonesia Economy and Business, 2007, Faculty of Economics of Gadjah Mada University, Indonesia.

Kasmir. (2014). Analisis Laporan Keuangan, Edisi Pertama, Cetakan Ketujuh. Jakarta: PT. Rajagrafindo Persada.

Kurniasih, T. \& Maria, M. R. S. (2013). Pengaruh Return On Assets, Leverage, Corporate Governance, Ukuran Perusahaan, dan Kompensasi Rugi Fiskal pada Tax Avoidance. Buletin Studi Ekonomi Vol 18, No.1, Halaman 58-65.

Maharani, I G. A. C., \& Suardana, K. A. (2014). Pengaruh Corporate Governance, Profitabilitas, dan Karakteristik Eksekutif Tax Avoidance Perusahaan Manufaktur. E-Jurnal Akuntansi Universitas Udayana ISSN: 2302-8556. 
Ngadiman, \& Puspitasari, C. (2014). Pengaruh Leverage, Kepemilikan Institusional, dan Ukuran Perusahaan terhadap Penghindaran Pajak (Tax Avoidance) pada Perusahaan Sektor Manufaktur yang Terdaftar di Bursa Efek Indonesia 2010-2012. Jurnal Akuntansi, Vol 18, No 3, Halaman 408-421.

Pranata, F. M. P. D.F \& Herawati. (2013). Pengaruh karakter Eksekutif dan Corporate Governance terhadap Tax Avoidamce. Skripsi. Padang: Universitas Bung Hatta.

Rachmithasari, A. F. (2015). Pengaruh Return On Assets, Leverage, Corporate Governance, Ukuran Perusahaan Dan Kompensasi Rugi Fiskal Pada Tax Avoidance (Perusahaan Manufaktur yang terdaftar di Bursa Efek Indonesia ). Jurnal Universitas Muhammadiyah Surakarta.

Richardson, G. \& Lanis, R. (2007). Determinants of Variability In Corporate Effective Tax Rates and Tax Reform: Evidence From Australia. Journal of Accounting and Public Policy 26 (2007) 689-704.

Sari, G. M. (2014). Pengaruh Corporate Governance, Ukuran Perusahaan, Kompensasi Rugi Fiskal, dan Struktur Kepemilikan Terhadap Tax Avoidance. Skripsi.Universitas Negeri Padang.

Suandy, E. (2008). Hukum Pajak. Edisi 4. Jakarta: Salemba Empat.

Swingly, C. (2015). Pengaruh Karakter Eksekutif, Komite Audit, Ukuran Perusahaan, Leverage dan Sales Growth Pada Tax Avoidance. E-Jurnal Akuntansi Universitas Udayana 10.1 (2015): 4762 .

Utami, C. W. (2013). Manajemen Ritel. Jakarta: Salemba Empat

Veronica, S., \& Siddharta, U. (2005). Pengaruh Struktur Kepemilikan, Ukuran Perusahaan, dan Praktek Corporate Governance terhadap Pengelolaan Laba (Earnings Management). Artikel yang Dipresentasikan pada Simposium Nasional Akuntansi. Solo.

Wening, K. (2009). Pengaruh Kepemilikan Institusional Terhadap Kinerja Keuangan Perusahaan. Zain. (2008). Manajemen Perpajakan. Jakarta: Salemba Empat. 